Paolo Migone

Some contributions on dreams published in the Italian journal Psicoterapia e Scienze Umane (»Psychotherapy and the Human Sciences«) 


\section{Impressum}

Psychotherapie-Wissenschaft

ISSN 1664-9583 (Print-Version)

ISSN 1664-9591 (digitale Version)

11. Jahrgang Heft $2 / 2021$

https://doi.org/10.30820/1664-9583-2021-2

info@psychotherapie-wissenschaft.info

www.psychotherapie-wissenschaft.info

\section{Herausgeber}

Schweizer Charta für Psychotherapie in der Assoziation

Schweizer Psychotherapeutinnen und Psychotherapeuten

Geschäftsstelle ASP

Riedtlistr. 8

CH-8006 Zürich

Tel. +41432689300

www.psychotherapie.ch

\section{Redaktion}

Mara Foppoli, Lugano

Lea-Sophie Richter, Zürich

Mario Schlegel, Zürich

Peter Schulthess, Zürich

Hinweise für AutorInnen befinden sich auf der Homepage der Zeitschrift: www.psychotherapie-wissenschaft.info

\section{Verlag}

Psychosozial-Verlag

Walltorstr. 10

D-35390 Gießen

+49642196997826

info@psychosozial-verlag.de

www.psychosozial-verlag.de

\author{
Abo-Verwaltung \\ Psychosozial-Verlag \\ bestellung@psychosozial-verlag.de
}

\section{Bezugsgebühren}

Jahresabonnement 44,90€ (zzgl. Versand)

Einzelheft $24,90 €$ (zzgl. Versand)

Studierende erhalten gegen Nachweis $25 \%$ Rabatt.

Das Abonnement verlängert sich um jeweils ein Jahr, sofern nicht eine Abbestellung bis acht Wochen vor Ende des Bezugszeitraums erfolgt.

ASP-Mitglieder wenden sich wegen des Abonnements bitte direkt an die ASP.

\section{Anzeigen}

Anfragen zu Anzeigen bitte an den Verlag:

anzeigen@psychosozial-verlag.de

Es gelten die Preise der auf www.psychosozial-verlag.de einsehbaren Mediadaten.

ASP-Mitglieder wenden sich bitte direkt an

die ASP-Geschäftsstelle: asp@psychotherapie.ch

\section{Digitale Version}

Die Zeitschrift Psychotherapie-Wissenschaft ist auch online einsehbar: www.psychotherapie-wissenschaft.info

\section{(C) $(1) \Theta$}

Die Beiträge dieser Zeitschrift sind unter der Creative Commons Attribution-NonCommercial-NoDerivs 3.0 DE Lizenz lizensiert. Diese Lizenz erlaubt die private Nutzung und unveränderte Weitergabe, verbietet jedoch die Bearbeitung und kommerzielle Nutzung. Weitere Informationen finden Sie unter: creativecommons.org/licenses/by-nc-nd/3.0/de 


\title{
Some contributions on dreams published in the Italian journal Psicoterapia e Scienze Umane ("1Psychotherapy and the Human Sciencesu)
}

\author{
Alcune pubblicazioni sul tema del sogno \\ apparse sulla rivista Psicoterapia e Scienze Umane \\ www.psicoterapiaescienzeumane.it
}

\author{
edited by/a cura di Paolo Migone \\ Psychotherapie-Wissenschaft 11 (2) 2021 67-69 \\ www.psychotherapie-wissenschaft.info \\ CC BY-NC-ND \\ https://doi.org/10.30820/1664-9583-2021-2-67
}

$1985,19(1), 7-26$

Fritz Morgenthaler, La diagnostica del sogno. Il significato dei punti di vista formali e strutturali (Dream diagnostics. The meaning of formal and structural points of view)

\section{$1987,21(2), 3-24$}

Fritz Morgenthaler, Un sogno come mezzo di prova (A dream as a means of proof)

1989, 23(2), 49-60

Nicoletta Collu, Adolfo Pazzagli \& Stefania Turillazzi, Il sogno in psicoterapia (The dream in psychotherapy)

1991, 25(1), 13-32

Kurt R. Eissler, Un addio a L'interpretazione dei sogni di Freud (A farewell to dream interpretation, 1985)

Riassunto: L'autore critica le interpretazioni di alcuni biografi di Freud al «sogno di Irma», sogno di fondamentale importanza esposto nel capitolo 2 dell'Interpretazione dei sogni e usato come esempio della tecnica di analisi dei sogni allora scoperta da Freud. Non è vero che Irma rappresenta Emma Eckstein, la paziente di Freud incautamente operata da Fliess, e comunque, anche se lo fosse, o se i sogni raccontati da Freud, così come pure gli esempi contenuti nella Psicopatologia della vita quotidiana, fossero tutti pura invenzione, ciò non toglierebbe nulla alla validità delle scoperte freudiane. Con tutta probabilità, i fattori determinanti il «sogno di Irma» sono la gravidanza della moglie (la sesta, che non era voluta), il sentimento di responsabilità di Freud, e il timore della morte della moglie; il triangolo «gravidanza-morte-colpa» è spesso uno stimolo per la creatività dell'essere umano di sesso maschile, e forse così fu anche per Freud riguardo alla fondamentale scoperta della interpretazione dei sogni.

Abstract: The author criticizes the interpretations given by some of Freud's biographers about «Irma's dream», a pivotal dream described in chapter 2 of The Interpretation of Dreams and used by Freud as an example of his newly discovered technique of dream analysis. Irma is not Emma Eckstein, the patient dangerously operated by Fliess, and at any rate, even if she was Emma, or if the dreams described by Freud, as well as the examples of The Psychopathology of Everyday Life, were completely fabricated, this would not diminish at all the importance of Freud's discoveries. Very likely, the factors behind Freud's «Irma's dream» are his wife's pregnancy (the sixth, which was unwanted), his feeling of responsibility, and the fear of his wife's death; the triad «pregnancy-death-guilt» is often a stimulus for male creativity, and perhaps this was true also for Freud's fundamental discovery of dream interpretation.

1991, 25(2), 91-109 (I parte) e 25(3), 89-113 (II parte)

Erik H. Erikson, Il sogno tipo della psicoanalisi (The dream specimen of psychoanalysis, 1954)

1993, 27(4), 63-81

Judith Valk, Lo sviluppo della teoria dei sogni in psicoanalisi: una revisione (The development of the theory of dreams in psychoanalysis: A revision)

Riassunto: L'interpretazione dei sogni, da Freud considerata il cuore della psicoanalisi, è ancora al centro dell'attività analitica? Cercando di rispondere a questo interrogativo, l'autrice, dopo aver messo in evidenza come l'avvento della psicologia dell'Io abbia notevolmente ridimensionato l'uso clinico dei sogni, prende in esame il contributo di alcuni autori postfreudiani: Erikson, Arlow e Brenner, French e Fromm, Klauber, e lo storico Schorske. Particolare attenzione è quindi dedicata al contributo di Morgenthaler, con il quale l'applicazione in questo campo della teoria strutturale trova finalmente la sua piena esplicazione.

Abstract: Is the interpretation of dreams, by Freud considered the heart of psychoanalysis, still at the center of analytic activity? Trying to answer this question, the author, after having shown how the advent of Ego psychology has much diminished the clinical use of dreams, takes into consideration the contribution of some postfreudian authors: Erikson, Arlow and Brenner, French and Fromm, Klauber, and the historian Schorske. Par- 
ticular attention receives Morgenthaler's contribution, whom the author attributes the merit to have eventually fully applied the structural theory in this field.

\section{0, 34(1), 5-30}

Wolfgang Mertens, L'interpretazione dei sogni, cent'anni dopo (Interpretation of dreams, one hundred years later)

Riassunto: La comprensione psicologica del sogno e l'interpretazione dei sogni basata su di essa sono state fortemente influenzate dalle idee di Sigmund Freud. Sia per gli amici che per i nemici delle concettualizzazioni freudiane, esse rimangono comunque il punto di partenza per ogni modifica o ulteriore sviluppo nel campo della comprensione del sogno. Oggi, tuttavia, anche per la maggior parte dei freudiani la teoria dei sogni di Freud non è più totalmente adeguata. La comprensione del sogno è cambiata molte volte durante questo secolo, anche all'interno della psicoanalisi, e ha registrato molti altri sviluppi nella teoria. In questo articolo, vengono mostrati anche i risultati offerti dal campo della psicologia cognitiva e delle neuroscienze, che negli ultimi vent'anni hanno prodotto uno sforzo enorme, contribuendo a far apparire alcuni assunti di Freud sotto un'altra luce.

Abstract: The psychological understanding of dream and the interpretation of dreams based on it have been strongly influenced by Sigmund Freud's ideas. Both for supporters and competitors of Freud's conceptions, they are still the point of departure for any change or further development in the understanding of dream. Nowadays, anyway, even for the most of Freudians, Freudian dream theory isn't seen as totally convincing any longer. The understanding of dream has changed many times during this century, even within psychoanalysis, and has shown many successive developments in the theory. In this paper, the outcomes offered by cognitive psychology and neurosciences are shown: in these last twenty years, they have produced a huge effort in order to shed a new light on some classical Freudian assumptions.

\section{8, 42(2), 163-178}

Paul Lippmann, Quando lo stile nevrotico dell'analista incontra il sogno (When the analyst's neurotic style meets the dream) (tratto da: Nocturnes. On Listening to Dreams. Hillsdale/NJ: Analytic Press, 2000, cap. 8)

Riassunto: Viene discusso il rapporto tra lo stile di personalità dello psicoanalista e il lavoro clinico con i sogni. In particolare, vengono analizzati sette stili di personalità dello psicoanalista mentre lavora con i sogni del paziente, e precisamente gli stili di personalità dell'analista compulsivo, ossessivo, isterico, narcisistico, schizoide, depressivo e paranoide. Per ognuno di questi stili di personalità vengono discussi i vantaggi e gli svantaggi, così pure come le specifiche caratteristiche, riguardo ad un ottimale lavoro terapeutico con i sogni.

Abstract: The relationship between the psychoanalyst's personality style and the clinical work with dreams is discussed. Seven neurotic styles of the analyst are reviewed and analyzed in their repercussions with the clinical use of dreams in analysis, namely the compulsive, the obsessive, the hysteric, the narcissistic, the schizoid, the depressive, and the paranoid personality styles.
For each of these personality style the disadvantages, as well as the advantages, are discussed in detail regarding the optimal clinical work with dreams.

\section{3, 47(1), 63-92}

Luigi Antonello Armando, Il sogno come trauma quotidiano e la responsabilità dell'interprete. Una rilettura de L'interpretazione dei sogni di Freud (Dream as daily trauma, and the interpreter's responsibility. A rereading of Freud's The Interpretation of Dreams)

Riassunto: A L'interpretazione dei sogni di Freud (1899) viene attribuito il merito di avere ridestato l'interesse per i sogni in quanto espressioni della realtà psichica e via regia alla sua conoscenza. Più di cento anni dopo, un romanziere giapponese (Haruki Murakami) prospetta il rischio di una scomparsa dei sogni che porta con sé quella della realtà psichica e del mondo umano. In questo articolo l'Autore si interroga sulla realtà di tale rischio. A tal fine rilegge il testo di Freud del 1899 - che sembra offrire la maggior garanzia contro di esso - storicizzandolo, ovvero cercando di definire il posto che occupa nella storia dell'interesse per i sogni e nella storia personale di Freud. Conclude che, contrariamente all'apparenza, proprio quel testo avvicina il rischio prospettato dal romanziere giapponese; lo porta anche a sostenere che la responsabilità di evitarlo dalla quale è investito l'interprete assume oggi la forma di una separazione da quel testo e in generale dal riconoscimento della realtà storica di Freud e dallo stabilimento di un esatto rapporto con essa.

Abstract: Freud's The Interpretation of Dreams (1900) has been considered the book that has reawaken the interest for dreams as manifestations of psychic reality and as the royal road to its knowledge. One hundred years later, a Japanese writer (Haruki Murakami) points out the risk that dreams disappear together with the disappearance of psychic reality and of human world as well. The Author of this paper reflects on the actuality of this risk. To this purpose, he rereads Freud's 1900 book - which seems to warrant against this risk - historicizing it, i.e., trying to understand its place in the history of the interest toward dreams and in Freud's personal history. The Author concludes that, against the appearance, Freud's 1900 book draws nearer the risk pointed out by the Japanese writer. He also concludes that, in order to avoid that risk, the interpreter's responsibility must assume today the form of a separation from that book, of a recognition of Freud's historical reality, and of a correct relation with this reality.

\section{6, 50(3), 606-609}

Frank J. Sulloway, Il crollo della teoria freudiana del sogno (The Demise of Freud's Dream Theory)

\section{9, 53(2), 281-298}

Luigi Antonello Armando, Stefano Benni, Marianna Bolko \& Alberto Merini, L'arte di sognare (The art of dreaming)

Riassunto: Il rapporto tra arte e sogno è all'origine della teoria del sogno di Freud. Nel secondo sogno che racconta, Dora sta in una città straniera, Dresda, ove ha incontrato un'opera di Raffaello, la Madonna Sistina, da cui è affascinata. Quando 
Freud le chiede cosa l'avesse colpita, risponde: «la Madonna». Freud interpreta che ad averla colpita era l'immagine della madre vergine, di una donna frigida perché diventata madre evitando il fantasma del trauma di un rapporto incestuoso. I quattro testi qui pubblicati, letti nell'incontro «L'arte di sognare» tenuto all'Istituzione Gian Franco Minguzzi di Bologna il 12 marzo 2019 in occasione della presentazione del libro di Luigi Antonello Armando e Marianna Bolko, Il trauma dimenticato. L'interpretazione dei sogni nelle psicoterapie: storia, teoria, tecnica (Milano: FrancoAngeli 2017), si chiedono se invece Dora cercasse nel trauma indottogli da quel quadro una capacità creativa a lei necessaria per proseguire il viaggio oltre la casa del padre. Essi si inseriscono nell'attuale dibattito sul sogno indagando, sulla base di questa domanda, la possibilità di andare oltre la teoria del sogno di Freud e la sua tecnica interpretativa.

Abstract: The relationship between art and dream is at the origin of Freud's dream theory. For example, Dora tells a dream in which she is in a foreign city, Dresden, where she is deeply fascinated by Raffaello's Sistine Madonna. When Freud asks what fascinated her, she replies: «the Madonna». From this answer, Freud confirms his dream theory by interpreting that what struck Dora was the image of a virgin mother, i. e., frigid because she became mother avoiding the fantasy of the trauma of an incestuous relationship. Four interventions are published, that were read at the meeting «The art of dreaming. Stefano Benni and Alberto Merini discuss with Luigi Antonello Armando and Marianna Bolko on the occasion of the presentation of their book The Forgotten Trauma. Dream Interpretation in the Psychotherapies: History, Theory, Technique (Milan: FrancoAngeli, 2017), held at the Gian Franco Minguzzi Institution of Bologna, Italy, on March 12, 2019. The authors make the hypothesis that in her reaction to that painting Dora, instead, was looking for the creative capacity she needed in order to leave her home and her father. On the basis of this hypothesis, they investigate the possibility of going beyond Freud's dream theory and his technique of dream interpretation.

\section{9, 53(4), 599-624}

Franco Maiullari, Bianca Maria de Adamich \& Marica Fragapane, Il finalismo del sogno nella Psicologia Individuale di Alfred Adler (Finalism of dreams in Alfred Adler's Individual Psychology)

Riassunto: Il finalismo psichico, inteso come prospettiva, progetto, vita orientata verso il futuro, è un principio generale del modello psicodinamico adleriano: esso opera a livello cosciente e inconscio, in modo esplicito e implicito, nella vita diurna così come nei sogni, ed è sempre riferito alla storia individuale, inserita in uno specifico contesto socio-culturale. Sulla base di queste premesse teoriche, nell'articolo: 1) viene posto il finalismo psichico in una prospettiva evoluzionistica; 2 ) vengono presentati alcuni sogni in cui il senso finalistico si esprime in modo pregnante; 3) si ipotizza che il sogno - e più in generale quella che si può chiamare capacità «fantasticonirica» dell'uomo colori di sé la vita psichica con una funzione catalizzatrice, sia nell'arte (Nietzsche e l'orizzonte estetico) sia nell'arte di vivere (Adler e l'orizzonte psicodinamico e psicoterapeutico).

Abstract: Psychic finalism, understood as perspective, project, or future-oriented life, is a general Adlerian psychodynamic principle. It operates on a conscious and on an unconscious level, in an explicit and in an implicit way, in daily life as well as in dreams; it is always seen in reference to the individual history and within a specific social and cultural context. Based on these theoretical indications, in this article: 1) psychic finalism is placed in an evolutionary perspective; 2 ) some clinical cases are presented in which the dream's finalism is expressed in a meaningful way; 3 ) it is hypothesized that the dream - and in a wider terms what could be defined the «fantastic-oneiric» capacity of the human being - colors psychic life with a catalyst function, both in art (as in Nietzsche's aesthetic perspective) and in the art of living (as in Adler's psychodynamic and psychotherapeutic perspectives). However, dreams today are still an enigmatic product of psychic life, and if we think at their emergence in the course of evolution we can only make some heuristic hypotheses on the reason why they have been selected and maintained, and on the anthropological meaning of their manifestation; at any rate, dreams are still a precious gift within a psychodynamic therapy because they surely tell something about the patient's mental life that we should investigate. 